\title{
Skills Acquisition Shortfall: A Study of Professional Accounting Education
}

\author{
Gohar Saleem Parvaiz ${ }^{1}$, Owais Mufti ${ }^{2}$, Muhammad Wahab ${ }^{3}$
}

\begin{abstract}
Previously, there was a paucity of empirical literature to illustrate the educators' performance of professional accounting institutions in Pakistan. Therefore, this research investigates the skills acquisition shortfall in professional accounting institutes of Pakistan. In this regard, independent sample t-test and principal component analysis is employed to draw statistical findings. Out of the 35 investigated skills, 24 skills were found to be undeveloped in students for employment purposes benchmarked against employers' expectations. Further, this research has proposed a skills acquisition framework comprising of 6 components of skills. These components of skills now could be viewed as a skills acquisition framework from professional accounting education perspective.
\end{abstract}

Keywords: Skills acquisition shortfall, accounting education, competence, employers, educators

\section{Introduction}

Since the early 1960's, human capital theory has been the most influential economic theory of the western world, used for framing government policies for education reforms to enhance people's employability. In this regard, Fitzsimons (1999) stated:

In terms of structural reform, under Human Capital Theory the basis for nation state structural policy frameworks is the enhancement of labour flexibility through regulatory reform in the labour market, as well as raising skill levels of additional investment in education, training and employment schemes, and immigration focused on attracting high-quality human capital. (p. 1)

To date available literature reports that investment in human capital in the form

1 Assistant Professor, Institute of Management Sciences, Peshawar. Email: gohar.saleem@imsciences. edu.pk

2 Assistant Professor, Institute of Management Sciences, Peshawar. Email: owais.mufti@imsciences. edu.pk

3 Center of Excellence in Islamic Finance (CEIF), Institute of Management Sciences, Peshawar.

Email: muhammadwahab55@gmail.com

ARTICLE HISTORY
\begin{tabular}{lll}
$21 \mathrm{Dec}, 2016$ Submission Received & 5 Feb, 2017 & First Review \\
\hline $17 \mathrm{Feb}, 2017$ Revised Version Received & 4 Mar, 2017 & Second Review \\
\hline $11 \mathrm{Mar}, 2017$ Revised Version Received & $30 \mathrm{Mar}, 2017$ & Accepted
\end{tabular}


of knowledge and skills through education has a significant impact on individuals, organizations and the country's overall economic growth (Blundell, Dearden, \& Meghir, 1999). Under human capital theory economists regard education as an economic good which is a means of providing utility on consumption and serves as an input for the production process of other goods and services. Hence, considering this, many governments around the world are now concerned with higher education system to enhance the capability of their human stock for enhanced productivity. For example, UK's HM Treasury (2000) stated:

Human capital directly increases productivity by raising the productive potential of employees. Improving skills and human capital are important in promoting growth, both as an input to production and by aiding technological progress. This has been recognized both in endogenous growth theory and also in empirical studies comparing growth in different countries. (p. 26, 32)

But due to the dominance of economic and political powers in the 21st century, it has been noticed that the higher education programs have been influenced more by the 'social efficiency ideology' in 'curriculum theory' than others (Russell, 2014). The 'social efficiency ideology' intends to design an education curriculum to maximize the 'social utility or productivity' of an individual for a societal future (Schiro, 2012). This phenomenon seems more apparent in professional accounting education where teachers are considered as a "technicians" with a responsibility to teach 'skills' to students that make students more fit for employment (Russell, 2014). In this regard, Lessenger and Salowe (2001) depicted the 'social efficiency ideology', by relating employable skills to a quality education system, cited by Schiro (2012) as, "a quality education system is an absolute essential to the economic, political, and social welfare of the United States... there is a consensus that students need employable skills for the new economy" (p. 79). Higher education institutions are considered as a mediating agent between the loosened boundaries between government and businesses (Morley, 2001) and employability of graduates (human stock) is an aim that governments around the world want to achieve by bringing about various reforms to their higher education systems (Yorke, 2006). This interest in employability through creation of skills in professional education reflects part of human capital theory (Yorke, 2006) and the aim of this research. This paper specifically aims to focus on skills acquisition shortfall in professional accounting education benchmarked against employers' expectation; give rise to the following research objective ( $\mathrm{RO} 1$ ) evaluating differences in perception between the two audiences (accounting educators and employers):

RO1: What are the perceptual dissimilarities between accounting educators and employers in terms of skills, competence expected to be developed in students? 
Further, this research also aims, in part, to redress determination of employment related skills in groups which are pertinent for professional accounting education; giving rise to second research objective:

RO2: What is the grouping of skills-acquisition from the perspective of professional accounting education?

The rest of the paper is organized as follows: Section 2 presents the literature reviewed; Section 3 discusses the methodology; analysis and discussion of results are presented in Section 4; Section 5 concludes the paper.

\section{Literature Review}

Gati (1998) stated if employment related skills don't develop in accounting students, this limits the opportunities for them to secure future employment. In the UK, this apparent shortfall is exacerbated by a skills-acquisition policy centered upon obtaining qualifications, first and foremost, with the acquisition of employment related skills being limited by that focus (see Knight \& Yorke, 2003; Yorke, 2006). Comparatively, in Pakistan, there is a paucity of evidence either way. And yet, various organizations, such as state departments and professional bodies, together with individual researchers, have repeatedly emphasized the need to expand skills acquisition in higher education institutions as a means of promoting graduate employability (see Cranmer, 2006; Quality Assurance Agency, 2007; Coopers \& Lybrand, 1998; Hillage \& Pollard, 1998; Dearing report, 1997; Council for Industry and Higher Education, 1996; Department of Trade and Industry, 2005).

The rallying cry for greater skills acquisition is present, above, and yet the reality is that there is no definitive list of skills or even a standard categorization among the various disciplines (see McQuaid \& Lindsay, 2005; Jones \& Sin, 2003; Wellman, 2010; Business Industry Higher Education Collaboration Council, 2007). The accounting discipline is no exception (see Jones \& Sin, 2003; Kavanagh, Hancock, Howieson, Kent, \& Tempone, 2009; Hassall, Joyce, Montaño, \& Anes, 2005; International Federation of Accountants, 2008; Albrecht \& Sack, 2000).

Accounting students and employers both consistently 'valued' employment related generic skills acquisition (see Kavanagh \& Drennan, 2008; Hassall et al., 2003), however, from an employer's perspective, students were consistently reported in the literature as being inadequately prepared for the workplace in terms of possessing the necessary skills for that domain (see Awayiga, Onumah, \& Tsamenyi, 2010; Willcoxson, Wynder, \& Laing, 2010). Further, the literature demonstrates that accounting academics are the ones who are identified as being primarily responsible for the nurturing of such absent skills in students (Kavanagh et al., 2009; Hassall et al., 2005). 
And yet it is also clear that academics are failing to equip students with an adequate set of employment related skills necessary for professional accounting career (see Lin, Xiong, \& Liu, 2005; Kavanagh \& Drennan, 2007; Awayiga et al., 2010; Willcoxson et al., 2010; Bui \& Porter, 2010; Jackling \& Watty, 2010; Kavanagh et al., 2009). So, a necessary first step in redressing this situation is to identify the relevant skills in the accounting domain. There are bound to be contextual limitations in this regard too (see, Bui \& Porter, 2010, De Lange, Jackling, \& Gut, 2006; Kavanagh \& Drennan, 2007; Millner \& Hill, 2008) and not all of the identified skills in one context would necessarily be transferable to another contextual setting (Campbell, 2010).

There is a substantial amount of literature on skills development, and the limitations thereof, in developed countries such as the United Kingdom, New Zealand, Australia, America, and Canada (see Jackling \& Keneley, 2009; Harvey \& Bowers-Brown, 2004; Confederation of British Industry, 2009; Australian Chamber of Commerce and Industry, 2002; Kavanagh \& Drennan, 2007; Kavanagh et al., 2009; Milner \& Hill, 2008; Accounting Education Change Commission, 1990; Institute of Chartered Accountants in England and Wales, 2010; Hassall et al., 1999, 2001, 2003, 2005; Montano, Donoso, Hassall, \& Joyce, 2001; De Lange et al., 2006; Albrecht \& Sack, 2000; Sin \& Jones, 2003; Certified Practising Accountants, 2008; Gray \& Collison, 2002; Quality Assurance Agency, 2007; Bui \& Porter, 2010). However, in contrast, there is a paucity of similar literature from the underdeveloped Asian countries such as Pakistan, India, Indonesia, Thailand, Taiwan, and the Philippines. It is time this position changed. That said, such studies provide a welcome general starting point (see Table 1) to our investigation even though there are considerable variations in the skills deemed to be pertinent from an employers' (accounting practitioners) perspective (see Table 2) and an academic (accounting educator) perspective (see Table 3).

Table 1: Variability of Generic Skills in Accounting Discipline

\begin{tabular}{|c|c|c|}
\hline Jones and Sin (2003) & IFAC (2008) & Albrecht and Sack (2000) \\
\hline Routine Skills: & Intellectual skills: & Accounting Software \\
\hline Report writing & $\begin{array}{c}\text { The individual's ability to } \\
\text { locate, obtains, organize and } \\
\text { understand information from } \\
\text { human, print and electronic } \\
\text { sources }\end{array}$ & $\begin{array}{c}\text { Appreciation of cross cultural } \\
\text { diversity }\end{array}$ \\
\hline Computer literacy & $\begin{array}{c}\text { The capacity for inquiry, } \\
\text { research, logic and analytic } \\
\text { thinking, power of reasoning, } \\
\text { and critical analysis }\end{array}$ & Business Decision Modelling \\
\hline
\end{tabular}




\begin{tabular}{|c|c|c|}
\hline Analytic and design skills: & $\begin{array}{c}\text { The ability to identify and } \\
\text { solve unstructured problems in } \\
\text { unfamiliar settings }\end{array}$ & Change Management \\
\hline $\begin{array}{l}\text { Identify, find, evaluate, orga- } \\
\text { nise and manage information } \\
\text { and evidence }\end{array}$ & & Company Promotion \\
\hline Initiate and conduct research & Technical and functional skills: & Computer Literacy (I can use) \\
\hline $\begin{array}{l}\text { Analyse, reason logically, con- } \\
\text { ceptualise issues }\end{array}$ & $\begin{array}{l}\text { Numeracy (mathematical and } \\
\text { statistical applications) and IT } \\
\text { proficiency }\end{array}$ & $\begin{array}{c}\text { Computer Technology (Sys- } \\
\text { tems) }\end{array}$ \\
\hline $\begin{array}{l}\text { Solve problems and Construct } \\
\text { arguments }\end{array}$ & $\begin{array}{c}\text { Decision modelling and risk } \\
\text { analysis }\end{array}$ & Continuous Learning \\
\hline Interpret data and reports & Measurement and reporting & Creativity \\
\hline \multirow[t]{2}{*}{ Engage in ethical reasoning } & $\begin{array}{l}\text { Compliance with legislative } \\
\text { and regulatory requirements. }\end{array}$ & Critical Thinking \\
\hline & & Cross Cultural Appreciation \\
\hline Appreciative skills: & Personal skills: & Cross Cultural communication \\
\hline $\begin{array}{c}\text { Receive, evaluate and react to } \\
\text { new ideas }\end{array}$ & Self-management & Cultural Sensitivity \\
\hline $\begin{array}{l}\text { Adapt and respond positively } \\
\text { to challenges }\end{array}$ & $\begin{array}{l}\text { Initiative, influence and } \\
\text { self-learning }\end{array}$ & Customer Service Orientation \\
\hline $\begin{array}{l}\text { Make judgements derived from } \\
\text { one's own value framework }\end{array}$ & $\begin{array}{l}\text { The ability to select and assign } \\
\text { priorities within restricted } \\
\text { resources and organize work to } \\
\text { meet deadlines }\end{array}$ & Decision Making \\
\hline Think and act critically & $\begin{array}{l}\text { The ability to anticipate and } \\
\text { adapt to change }\end{array}$ & Entrepreneurship \\
\hline Know what questions to ask & $\begin{array}{l}\text { Considering the implications } \\
\text { of professional values ethics } \\
\text { and attitudes in decision } \\
\text { making }\end{array}$ & Ethics \\
\hline Engage in lifelong learning & Professional scepticism & Flexibility \\
\hline $\begin{array}{c}\text { Recognise one's own strengths } \\
\text { and limitations }\end{array}$ & & Foreign Language \\
\hline $\begin{array}{l}\text { Appreciate ethical dimensions } \\
\text { of situations }\end{array}$ & $\begin{array}{c}\text { Interpersonal and communica- } \\
\text { tion skills: }\end{array}$ & Good Citizenship \\
\hline $\begin{array}{l}\text { Apply disciplinary and multi- } \\
\text { disciplinary perspectives }\end{array}$ & $\begin{array}{c}\text { Work with others in a consul- } \\
\text { tative process, to withstand and } \\
\text { resolve conflict }\end{array}$ & Independent Thought \\
\hline
\end{tabular}




\begin{tabular}{|c|c|c|}
\hline $\begin{array}{l}\text { Appreciate process of pro- } \\
\text { fessional adaptation and } \\
\text { behaviour }\end{array}$ & Work in teams & Inter-disciplinarity \\
\hline & $\begin{array}{l}\text { Interact with culturally and } \\
\text { intellectually diverse people }\end{array}$ & Interpersonal \\
\hline Personal Skills: & $\begin{array}{c}\text { Negotiate acceptable solutions } \\
\text { and agreements in professional } \\
\text { situations }\end{array}$ & Leadership \\
\hline $\begin{array}{l}\text { Commitment to think and } \\
\text { behave ethically }\end{array}$ & $\begin{array}{l}\text { Work effectively in a cross-cul- } \\
\text { tural setting }\end{array}$ & Listening \\
\hline $\begin{array}{l}\text { Flexibility in new/different } \\
\text { situations }\end{array}$ & $\begin{array}{l}\text { Present, discuss, report and de- } \\
\text { fend views effectively through } \\
\text { formal, informal, written and } \\
\text { spoken communication }\end{array}$ & Logical Argument \\
\hline Act strategically & $\begin{array}{l}\text { Listen and read effectively, in- } \\
\text { cluding a sensitivity to cultural } \\
\text { and language differences. }\end{array}$ & Measurement (able to quantify) \\
\hline $\begin{array}{l}\text { Thinking and acting inde- } \\
\text { pendently }\end{array}$ & & Negotiation \\
\hline To be focused on outcomes & $\begin{array}{l}\text { Organizational and business } \\
\text { management skills: }\end{array}$ & Oral Communication \\
\hline Toleration of ambiguity & $\begin{array}{c}\text { Strategic planning, project } \\
\text { management, management } \\
\text { of people and resources, and } \\
\text { decision making }\end{array}$ & Problem Solving \\
\hline Creative thinking & $\begin{array}{c}\text { The ability to organize and } \\
\text { delegate tasks, to motivate and } \\
\text { to develop people }\end{array}$ & Professional Attitude \\
\hline & Leadership & Project Management \\
\hline Interpersonal skills: & $\begin{array}{l}\text { Professional judgment and } \\
\text { discernment. }\end{array}$ & Reading for Understanding \\
\hline Listen effectively & & Research \\
\hline $\begin{array}{c}\text { Present and discuss and defend } \\
\text { views }\end{array}$ & & Resource Management \\
\hline Transfer and receive knowledge & & Risk Analysis \\
\hline $\begin{array}{c}\text { Negotiation skills (with people } \\
\text { from different backgrounds } \\
\text { and with different value } \\
\text { systems) }\end{array}$ & & Risk Propensity \\
\hline Understanding group dynamics & & Self-Motivation \\
\hline
\end{tabular}




\begin{tabular}{|c|c|c|}
\hline $\begin{array}{c}\text { Collaboration skills (with } \\
\text { colleagues) }\end{array}$ & Self-Promotion \\
\hline & & Social Justice \\
\hline & & Strategic Management \\
\hline & & Teamwork \\
\hline & & Technical Bookkeeping \\
\hline & & Tenacity \\
\hline & & Values \\
\hline & & Work Ethic \\
\hline & & Written Communication \\
\hline
\end{tabular}

Table 2: Examples of Skills Identified by Employers

\begin{tabular}{|c|c|c|c|}
\hline $\begin{array}{l}\text { Hassall et al. (1999, } \\
\text { 2001, 2003, 2005) }\end{array}$ & Kavanagh et al. (2009) & Montano et al. (2001) & CPA (2008) \\
\hline Communication skills & Communication skills & Communication skills & Routine skills \\
\hline Group Working Skills & Presentation skills & $\begin{array}{c}\text { Stress management } \\
\text { skills }\end{array}$ & Analytic skills \\
\hline Problem Solving Skills & Teamwork skills & & Appreciative skills \\
\hline $\begin{array}{l}\text { Pressure and Time } \\
\text { Management Skills }\end{array}$ & $\begin{array}{c}\text { Good interpersonal } \\
\text { skills }\end{array}$ & & Personal skills \\
\hline $\begin{array}{l}\text { Information Technolo- } \\
\text { gy skills } \\
\end{array}$ & Fit organisations ethos & & Interpersonal skills \\
\hline \multirow{4}{*}{$\begin{array}{c}\text { Other Skills, Values } \\
\text { and Knowledge }\end{array}$} & Self-management skills & & \\
\hline & $\begin{array}{l}\text { Initiative and enter- } \\
\text { prise skills }\end{array}$ & & \\
\hline & $\begin{array}{l}\text { Technological compe- } \\
\text { tence }\end{array}$ & & \\
\hline & $\begin{array}{l}\text { Planning and organis- } \\
\text { ing skills }\end{array}$ & & \\
\hline
\end{tabular}


Table 3: Examples of Skills Identified by Educators

\begin{tabular}{|c|c|}
\hline Kavanagh and Drennan (2007) & Tan, Fowler, \& Hawkes (2004) \\
\hline Problem Solving skills & Problem solving skills \\
\hline Personal and Strategic Management skills & Thinking skills \\
\hline Routine Accounting skills & Listening skills \\
\hline Citizenship skills & Quantitative skills \\
\hline Cultural Sensitivity & Speaking skills \\
\hline Work Ethics & Writing skills \\
\hline Personal and Appreciative skills & Microcomputer skills \\
\hline & Reading skills \\
\hline & Management skills \\
\hline & Social skills \\
\hline & Marketing skills \\
\hline
\end{tabular}

\subsection{Target Audience}

A closed ended questionnaire based approach was used. In the early stages of the research we used the literature (as in Tables 1 - 3) and an interview based consultation process to identify those employments related skills necessary for inclusion in the questionnaire. That consultation was directed towards two target audiences (accounting educators and employers):

a. Educators; academics teaching in professional accounting institutes of Pakistan

In Pakistan, there are five accounting bodies providing certified accounting education, that is, the Institute of Chartered Accountants of Pakistan (ICAP); the Institute of Cost and Management Accountants of Pakistan (ICMAP); the Institute of Certified Public Accountants of Pakistan (ICPAP); the Society of Accounting Education (SOAE) and the Pakistan Institute of Public Finance Accountants (PIPFA). These professional bodies have 37 registered education centres across the country to provide professional accounting education. Unfortunately, unlike developed countries, in Pakistan there is no database available, providing information regarding number of educators working in accounting educational institutes (For example, in New Zealand - Wiley Directory of Accounting provides information about all available accounting academics). Therefore, pragmatically it was impossible to survey all educators, especially when the exact population size is not known. Therefore, in this research for the purpose of data collection, the targeted sample size was determined by observing the requirements of the analytical techniques that has been used (that are, Independent sample t-test and Principal Component Analysis). In total, 460 questionnaires were 
distributed among educators (academics teaching at the professional accounting institutes). Further follow-on calls have been made to head (Principal/director/dean) of the institutes to request them to help in the collection of the questionnaires circulated among their faculty members. In response, 201 usable questionnaires were returned. Unusable questionnaires were half filled questionnaires.

b. Employers; accounting practitioners working in professional organisations of Pakistan

From the employers' perspective, the only list of professional organisations that are registered with accounting educational bodies are 170 auditing firms registered as training partners (for student articleship). Similarly, like educators there is also no database available, providing information regarding the number of accounting practitioners working in these auditing firms in Pakistan. In total, 1020 questionnaires were distributed among accounting practitioners at the organizations (auditing firms) where they work. In response, 204 usable questionnaires were returned. Unusable questionnaires were half filled questionnaires.

See Table 4 representing demographic details (gender, age, work experience, position, professional education and general academic qualification) from the respondent groups (accounting employers and educators).

Table 4: Representing the Demographic Details of the Respondents

\begin{tabular}{|c|c|c|c|}
\hline Demographic & Category & Employers group & Educators groups \\
\hline \multirow[t]{2}{*}{ Gender } & Male & 199 (97.5\%) & $188(93.5 \%)$ \\
\hline & Female & $5(2.5 \%)$ & $13(6.5 \%)$ \\
\hline \multirow[t]{5}{*}{ Age } & 20-24 years & - & $3(1.5 \%)$ \\
\hline & $25-35$ years & $132(64.7 \%)$ & $144(70.1 \%)$ \\
\hline & $36-44$ years & $63(30.9 \%)$ & $52(25.9 \%)$ \\
\hline & $45-54$ years & $8(3.9 \%)$ & $5(2.5 \%)$ \\
\hline & 55-above & $1(0.5 \%)$ & - \\
\hline \multirow[t]{5}{*}{ Experience } & Less than a year & - & $2(1 \%)$ \\
\hline & $1-3$ years & - & $131(65.2 \%)$ \\
\hline & 4-7 years & $48(23.5 \%)$ & $44(21.9 \%)$ \\
\hline & $8-10$ years & $113(55.4 \%)$ & $19(9.5 \%)$ \\
\hline & 11 years and more & $43(21.2 \%)$ & $5(2.5 \%)$ \\
\hline
\end{tabular}




\begin{tabular}{|c|c|c|c|}
\hline \multirow[t]{5}{*}{ Position } & Top level executive & $26(12.7 \%)$ & $\mathrm{N} / \mathrm{A}$ \\
\hline & Middle level executive & $165(80.9 \%)$ & $\mathrm{N} / \mathrm{A}$ \\
\hline & Others & $13(6.4 \%)$ & $\mathrm{N} / \mathrm{A}$ \\
\hline & Full time academic & $\mathrm{N} / \mathrm{A}$ & $57(28.4 \%)$ \\
\hline & Part time academic & $\mathrm{N} / \mathrm{A}$ & $144(71.6 \%)$ \\
\hline \multirow{2}{*}{$\begin{array}{l}\text { Participants who had } \\
\text { Professional account- } \\
\quad \text { ing education }\end{array}$} & Yes & $204(100 \%)$ & 35 (17.4\%) \\
\hline & No & - & $166(82.5 \%)$ \\
\hline \multirow[t]{5}{*}{$\begin{array}{c}\text { General academic } \\
\text { qualification }\end{array}$} & $\begin{array}{l}\text { Higher Secondary } \\
\text { School Certificate }\end{array}$ & $96(47.1 \%)$ & $16(8 \%)$ \\
\hline & Bachelor degree & $99(48.5 \%)$ & $91(45.3 \%)$ \\
\hline & Master degree & $9(4.4 \%)$ & $64(31.8 \%)$ \\
\hline & Masters of Philosophy & - & $30(14.9 \%)$ \\
\hline & Doctorate & - & - \\
\hline
\end{tabular}

\section{Methodology}

In this research for the collection of data a closed ended questionnaire based approach was used.

In this research when we refer to a 'skills acquisition shortfall' that shortfall arises from the investigation of 'the perceptual differences in the level of skills that educators expect students to acquire by the time they graduate' and 'those skills which employers perceive the graduates should possess when they enter the profession'. This implies measuring the views on competence of 5-point Likert scale (1 No competence ...5 High competence) from accounting employers and educators separately. Thus, there were two sets of a questionnaire: one evaluating the views from the educators' perspective, while the other from the employers. Later the views from both respondent groups were combined to investigate the overall 'skills acquisition shortfall'.

Initially, in order to develop a questionnaire, survey instrument included a list of skills adopted by prior literature (such as Jones \& Sin, 2003; Hassall et al., 1999, 2001, 2003, 2005; International Federation of Accountants, 2008; American Institute of Certified Public Accountants, 1998; Albrecht \& Sack, 2000; Kavanagh \& Drennan, 2007, 2008; Kavanagh et al., 2009; Lin et al., 2005; Jackling \& Keneley, 2009). But as Jones (2010) stated individuals from different disciplines define skills differently. Therefore, the adopted list of skills from prior literature (as stated above) were revised to include a skills description through the cognitive interviews process ( 3 interviews from educators and 3 interviews from employers). This step was important for the common understanding of the survey instrument respondents. Appendix 1 shows 
the list of skills with their description that were used in the surveyed questionnaire.

For analysis of RO1 the collected data from the respondent groups complies normal distributed assumption and, as such, Independent sample t-test was used. Conversely, for analysis of RO2, Principal Component Analysis (PCA) with a Varimax rotation was performed in respect of the data collected from the employers' group only.

\section{Analysis and Results}

From Table 5, one can see the values of the independent sample t-test for each of the 35 evaluated skills (6th column from the left). Out of the 35 skills, 11 skills (values without ${ }^{* *}$ ) were found to have statistically insignificant differences (values without ${ }^{* *}$ ), which means the respondent groups (employers and educators) shared similar views over such skills. It follows that the remaining 24 skills (values with ${ }^{* *}$ )

Table 5: Representing the results of Independent Sample t-test with Competence Mismatch Score

\begin{tabular}{|c|c|c|c|c|c|}
\hline S. & Skills terminologies & $\begin{array}{c}\text { Employers } \\
\text { Competence } \\
\text { score (repre- } \\
\text { senting Mean } \\
\text { value) }\end{array}$ & $\begin{array}{c}\text { Educators } \\
\text { Competence } \\
\text { Score (repre- } \\
\text { senting Mean } \\
\text { value) }\end{array}$ & $\begin{array}{c}\text { RO1 } \\
\text { Competence } \\
\text { mismatch } \\
\text { (representing } \\
\text { gap) }\end{array}$ & $\begin{array}{c}\text { Independent } \\
\text { Sample t-test } \\
\text { (Significance } \\
\text { level at 5\%) }\end{array}$ \\
\hline 1 & Decision making & 3.91 & 3.44 & .472 & $.000^{* *}$ \\
\hline 2 & Financial risk analysis & 3.61 & 3.38 & .228 & $.012^{* *}$ \\
\hline 3 & Financial accounting & 4.23 & 4.24 &. .013 & .870 \\
\hline 4 & $\begin{array}{c}\text { Information technology } \\
\text { competence }\end{array}$ & 3.48 & 3.30 & .172 & .087 \\
\hline 5 & Critical thinking & 4.02 & 4.00 & .020 & .814 \\
\hline 6 & $\begin{array}{c}\text { International global } \\
\text { perspective }\end{array}$ & 3.96 & 3.78 & .171 & .053 \\
\hline 7 & Legal regulatory per- & 4.02 & 3.92 & .104 & .217 \\
\hline 8 & Marketing/clients focus & 3.00 & 1.97 & 1.020 & $.000^{* *}$ \\
\hline 9 & Problem solving & 3.76 & 3.58 & .181 & .068 \\
\hline 10 & Leadership & 3.16 & 2.27 & .892 & $.000^{* *}$ \\
\hline 11 & Project management & 3.40 & 2.25 & 1.151 & $.000^{* *}$ \\
\hline 12 & $\begin{array}{c}\text { Think and behave } \\
\text { ethically }\end{array}$ & 2.94 & 2.60 & .336 & $.001^{* *}$ \\
\hline 13 & $\begin{array}{c}\text { Flexibility and adapt- } \\
\text { ability }\end{array}$ & 3.29 & 2.18 & 1.114 & $.000^{* *}$ \\
\hline
\end{tabular}




\begin{tabular}{|c|c|c|c|c|c|}
\hline 14 & Strategic management & 3.19 & 3.06 & .132 & .176 \\
\hline 15 & Independent thinking & 2.96 & 2.62 & .347 & $.000^{* *}$ \\
\hline 16 & Focused on outcome & 3.47 & 3.40 & .071 & .451 \\
\hline 17 & Tolerate ambiguity & 2.79 & 1.79 & 1.003 & $.000^{* *}$ \\
\hline 18 & Think creatively & 3.38 & 2.45 & .937 & $.000^{* *}$ \\
\hline 19 & Listen effectively & 3.34 & 2.84 & .503 & $.000^{* *}$ \\
\hline 20 & Presentation skills & 3.47 & 2.49 & .976 & $.000^{* *}$ \\
\hline 21 & Negotiation skills & 3.32 & 2.42 & .897 & $.000^{* *}$ \\
\hline 22 & $\begin{array}{l}\text { Understanding group } \\
\text { dynamics }\end{array}$ & 2.89 & 1.99 & .904 & $.000^{* *}$ \\
\hline 23 & $\begin{array}{l}\text { Communicate in writ- } \\
\text { ten format }\end{array}$ & 3.35 & 3.31 & .040 & .687 \\
\hline 24 & Communicate orally & 3.40 & 2.51 & .889 & $.000^{* *}$ \\
\hline 25 & $\begin{array}{c}\text { Engage in lifelong } \\
\text { learning }\end{array}$ & 2.96 & 1.96 & .996 & $.000^{* *}$ \\
\hline 26 & $\begin{array}{l}\text { Inter or multidisci- } \\
\text { plinary perspective }\end{array}$ & 3.63 & 3.43 & .197 & $.047^{* *}$ \\
\hline 27 & Teamwork & 3.53 & 2.79 & .743 & $.000^{* *}$ \\
\hline 28 & $\begin{array}{c}\text { Ability to analyse and } \\
\text { reason logically }\end{array}$ & 3.99 & 3.52 & .479 & $.000^{* *}$ \\
\hline 29 & Personal attributes & 3.03 & 2.07 & .965 & $.000^{* *}$ \\
\hline 30 & $\begin{array}{l}\text { Work effectively in di- } \\
\text { versified cultural settings }\end{array}$ & 2.77 & 1.86 & .914 & $.000^{* *}$ \\
\hline 31 & Self-initiative & 3.20 & 2.16 & 1.039 & $.000^{* *}$ \\
\hline 32 & English language & 3.59 & 2.64 & .949 & $.000^{* *}$ \\
\hline 33 & Statistics & 3.41 & 3.45 & -.031 & .763 \\
\hline 34 & $\begin{array}{c}\text { Cost and management } \\
\text { accounting }\end{array}$ & 4.13 & 4.01 & .122 & .159 \\
\hline 35 & Economics & 3.13 & 2.75 & .377 & $.000^{* *}$ \\
\hline
\end{tabular}

** Independent sample T-test is statistically significant at 0.05 alpha level.

In independent sample t-test, if the sig (2-tailed) value is greater than 0.05 then it means that the mean difference between two groups' value is statistically insignificant. This can be interpreted as the mean difference between group 1 (G1) and group 2 (G2) values is by chance, therefore accept null hypothesis (Ho: G1=G2). However, if the sig (2-tailed) value is less than 0.05 then it means that the mean difference between the two group values is statistically significant. This can be interpreted as the mean difference between the group 1 (G1) and group 2 (G2) is not by chance, therefore reject the null hypothesis and accept alternative hypothesis (H1: G1FG2) (Laerd Statistics, 2013). 
were found to have significant differences, which means the respondent groups (employers and educators) do not share similar views over such skills.

From Table 5, for the employers group, one can see that the mean score regarding the skills ranges from 2.77 (work effectively in diversified cultural settings) to 4.23 (Financial accounting). In contrast, for the educators group, the mean score ranges from 1.79 (Tolerate ambiguity) to 4.24 (Financial accounting). One can see the mismatch in competence scores from Table 5 (4th column from the left) that is, representing the shortfall of accounting educators in developing the skills in students desired by accounting employers. In considering the independent sample t-test values (values

Table 6: Representing the Categorisation of Skills Considering the Results of Independent Sample t-test with Competence Mis-match Score

\begin{tabular}{|c|c|c|c|c|}
\hline & \multicolumn{2}{|c|}{$\begin{array}{l}\text { Category } 1 \text { - Insignificant differences } \\
\text { Skills having insignificant differences - the } \\
\text { perceived competence expected to be de- } \\
\text { veloped in students by educators coincides } \\
\text { with the competence expected by employ- } \\
\text { ers for the purpose of employment. }\end{array}$} & \multicolumn{2}{|c|}{$\begin{array}{l}\text { Category } 2 \text { - Significant differences } \\
\text { Skills having significant differences - the } \\
\text { perceived competence expected to be de- } \\
\text { veloped in students by educators does not } \\
\text { coincide with the competence expected by } \\
\text { employers for the purpose of employment. }\end{array}$} \\
\hline $\begin{array}{l}\text { S. } \\
\text { No. }\end{array}$ & $\begin{array}{c}\text { List of } 11 \text { Generic } \\
\text { skills }\end{array}$ & $\begin{array}{l}\text { Mismatch compe- } \\
\text { tence score }\end{array}$ & $\begin{array}{c}\text { List of } 24 \text { Generic } \\
\text { skills }\end{array}$ & $\begin{array}{l}\text { Mismatch compe- } \\
\text { tence score }\end{array}$ \\
\hline 1 & Financial accounting &. .013 & $\begin{array}{l}\text { Inter or multidisci- } \\
\text { plinary perspective }\end{array}$ & $0.197^{* *}$ \\
\hline 2 & Statistics & -0.031 & $\begin{array}{c}\text { Financial risk } \\
\text { analysis }\end{array}$ & $0.228^{* *}$ \\
\hline 3 & Critical thinking & 0.020 & $\begin{array}{c}\text { Think and behave } \\
\text { ethically }\end{array}$ & $0.336^{* *}$ \\
\hline 4 & $\begin{array}{l}\text { Communicate in } \\
\text { written format }\end{array}$ & 0.040 & $\begin{array}{l}\text { Independent } \\
\text { thinking }\end{array}$ & $0.347^{* *}$ \\
\hline 5 & $\begin{array}{l}\text { Focused on out- } \\
\text { comes }\end{array}$ & 0.071 & Decision making & $0.472^{* *}$ \\
\hline 6 & $\begin{array}{l}\text { Legal regulatory } \\
\text { perspective }\end{array}$ & 0.104 & Economics & $0.377^{* *}$ \\
\hline 7 & $\begin{array}{l}\text { Cost and manage- } \\
\text { ment accounting }\end{array}$ & 0.122 & $\begin{array}{l}\text { Ability to analyse } \\
\text { and reason logically }\end{array}$ & $0.479^{* *}$ \\
\hline 8 & $\begin{array}{l}\text { Strategic manage- } \\
\text { ment }\end{array}$ & 0.132 & Listen effectively & $0.503^{* *}$ \\
\hline 9 & $\begin{array}{l}\text { International global } \\
\text { perspective }\end{array}$ & 0.171 & Teamwork & $0.743^{* *}$ \\
\hline
\end{tabular}




\begin{tabular}{|c|c|c|c|c|}
\hline 10 & $\begin{array}{l}\text { Information technol- } \\
\text { ogy competence }\end{array}$ & 0.172 & Leadership & $0.892^{* *}$ \\
\hline 11 & Problem solving & 0.181 & Negotiation skills & $0.897^{* *}$ \\
\hline 12 & & & Communicate orally & $0.889^{* *}$ \\
\hline 13 & & & $\begin{array}{l}\text { Understanding } \\
\text { group dynamics }\end{array}$ & $0.904^{* *}$ \\
\hline 14 & & & $\begin{array}{l}\text { Work effectively in } \\
\text { diversified cultural } \\
\text { settings }\end{array}$ & $0.914^{* *}$ \\
\hline 15 & & & Think creatively & $0.937^{* *}$ \\
\hline 16 & & & English language & $0.949^{* *}$ \\
\hline 17 & & & Personal attributes & $0.965^{* *}$ \\
\hline 18 & & & Presentation skills & $0.976^{* *}$ \\
\hline 19 & & & $\begin{array}{c}\text { Engage in lifelong } \\
\text { learning }\end{array}$ & $0.996^{* *}$ \\
\hline 20 & & & Tolerate ambiguity & $1.003^{* *}$ \\
\hline 21 & & & $\begin{array}{l}\text { Marketing/clients } \\
\text { focus }\end{array}$ & $1.020^{* *}$ \\
\hline 22 & & & Self-initiative & $1.039^{* *}$ \\
\hline 23 & & & $\begin{array}{l}\text { Flexibility and adapt- } \\
\text { ability }\end{array}$ & $1.114^{* *}$ \\
\hline 24 & & & Project management & $1.151^{* *}$ \\
\hline
\end{tabular}

${ }^{* *}$ Independent sample T-test; competence mismatch score is statistically significant at 0.05 alpha level.

in 6th column), the skills items were classified into two categories in Table 6, that is, Category 1 (Insignificant differences) and Category 2 (Significant differences).

Having identified significant differences in perception between the two groups (employers and educators) regarding generic skills development, the analysis focuses next on RO2. This objective was directed towards the development of a framework outlining the main employment-related skills that educational institutes should be focused upon in order to, arguably, improve employability amongst their students.

In order to conduct an appropriate principal component analysis (PCA) Norusis (1992) recommends the use of the Kaiser-Meyer-Olkin (KMO) test and the Bartlett test of Sphericity first. In this study, the KMO was 0.816 , which was greater than 0.5 and as such this suggests the observed data is suitable for PCA (see Tabachnick \& Fidell, 2007). Further the value of Bartlett's test of Sphericity 'sig' value was 0.000 indicating that there exists a statistically significant correlation among the observed variables 
(items). Therefore, the data is suitable for PCA (see Hair, Black, Babin, Anderson, $\&$ Tatham 2006). Then the communality for each of the observed items (skills) was evaluated. All of the 35 observed items (skills per Table 5) in this study were showing communality greater than 0.4 (40\%), which means none of the observed items (skills) represents a weak correlation. Therefore, none of the observed items (skills) were removed from the items list and all of them were considered for the analysis. Table 7 shows the total variance explained by each component extracted as a result of PCA. Only the number of components that contribute to an Eigenvalue of greater than 1 were significant. As a consequence, only first 6 components were retained and the remainder of the components were discarded. An inspection of the plotted

Table 7: Total Variance Explained ${ }^{a}$

\begin{tabular}{|c|c|c|c|c|c|c|c|c|c|}
\hline \multirow[t]{2}{*}{$\begin{array}{l}\text { Com- } \\
\text { ponent }\end{array}$} & \multicolumn{3}{|c|}{ Initial Eigenvalues } & \multicolumn{3}{|c|}{$\begin{array}{l}\text { Extraction Sums of } \\
\text { Squared Loadings }\end{array}$} & \multicolumn{3}{|c|}{$\begin{array}{c}\text { Rotation Sums of Squared } \\
\text { Loadings }\end{array}$} \\
\hline & Total & $\begin{array}{l}\% \text { of } \\
\text { Vari- } \\
\text { ance }\end{array}$ & $\begin{array}{c}\text { Cumu- } \\
\text { lative } \\
\%\end{array}$ & Total & $\begin{array}{l}\% \text { of } \\
\text { Vari- } \\
\text { ance }\end{array}$ & $\begin{array}{c}\text { Cumu- } \\
\text { lative } \\
\%\end{array}$ & Total & $\begin{array}{l}\% \text { of } \\
\text { Vari- } \\
\text { ance }\end{array}$ & $\begin{array}{c}\text { Cumu- } \\
\text { lative } \\
\%\end{array}$ \\
\hline 1 & 8.123 & 23.208 & 23.208 & 8.123 & 23.208 & 23.208 & 4.798 & 13.708 & 13.708 \\
\hline 2 & 4.115 & 11.758 & 34.966 & 4.115 & 11.758 & 34.966 & 4.219 & 12.053 & 25.761 \\
\hline 3 & 3.036 & 8.675 & 43.641 & 3.036 & 8.675 & 43.641 & 3.980 & 11.370 & 37.131 \\
\hline 4 & 2.833 & 8.093 & 51.735 & 2.833 & 8.093 & 51.735 & 3.278 & 9.366 & 46.498 \\
\hline 5 & 2.261 & 6.461 & 58.196 & 2.261 & 6.461 & 58.196 & 2.849 & 8.140 & 54.638 \\
\hline 6 & 1.485 & 4.244 & 62.440 & 1.485 & 4.244 & 62.440 & 2.731 & 7.802 & 62.440 \\
\hline 7 & .979 & 2.797 & 65.237 & & & & & & \\
\hline 8 & .961 & 2.747 & 67.984 & & & & & & \\
\hline 9 & .875 & 2.501 & 70.485 & & & & & & \\
\hline 10 & .830 & 2.372 & 72.857 & & & & & & \\
\hline 11 & .803 & 2.294 & 75.151 & & & & & & \\
\hline 12 & .722 & 2.064 & 77.215 & & & & & & \\
\hline 13 & .673 & 1.924 & 79.139 & & & & & & \\
\hline 14 & .644 & 1.840 & 80.979 & & & & & & \\
\hline 15 & .586 & 1.674 & 82.652 & & & & & & \\
\hline 16 & .559 & 1.599 & 84.251 & & & & & & \\
\hline 17 & .499 & 1.425 & 85.676 & & & & & & \\
\hline 18 & .468 & 1.339 & 87.015 & & & & & & \\
\hline 19 & .442 & 1.264 & 88.278 & & & & & & \\
\hline 20 & .423 & 1.209 & 89.487 & & & & & & \\
\hline
\end{tabular}




\begin{tabular}{|l|c|c|c|l|l|l|l|l|l|}
\hline 21 & .367 & 1.049 & 90.536 & & & & & & \\
\hline 22 & .364 & 1.039 & 91.575 & & & & & & \\
\hline 23 & .336 & .959 & 92.533 & & & & & & \\
\hline 24 & .322 & .921 & 93.454 & & & & & & \\
\hline 25 & .282 & .807 & 94.261 & & & & & & \\
\hline 26 & .265 & .757 & 95.018 & & & & & & \\
\hline 27 & .259 & .741 & 95.759 & & & & & & \\
\hline 28 & .230 & .657 & 96.415 & & & & & & \\
\hline 29 & .225 & .644 & 97.060 & & & & & & \\
\hline 30 & .214 & .610 & 97.670 & & & & & & \\
\hline 31 & .197 & .564 & 98.234 & & & & & & \\
\hline 32 & .193 & .550 & 98.784 & & & & & & \\
\hline 33 & .174 & .497 & 99.281 & & & & & & \\
\hline 34 & .146 & .416 & 99.697 & & & & & & \\
\hline 35 & .106 & .303 & 100.000 & & & & & & \\
\hline
\end{tabular}

Extraction Method: Principal Component Analysis.

a. Only cases for which group = Employers are used in the analysis phase.

line (Scree-plot) also confirmed 6 components. These 6 components cumulatively explained $62.440 \%$ of the total variance (see column 'cumulative \%' in Table 7).

Lastly, Table 8 represents the rotated pattern matrix that displays the six-component solution. Loaded components psychometrists suggest omitting the items having a loading of less than 0.4 (Churchill, 1979). This is because psychometrists believe that such items reveal a weak correlation with the loaded components. Therefore, such items have been deleted from the component matrix because they have a negligible effect on the loaded components. Thus, items that are loaded equal to or less than 0.4 within this research were deleted from the rotated pattern matrix (see Table 8). In

Table 8: Rotated Component Matrixa,b

\begin{tabular}{|c|c|c|c|c|c|c|}
\hline & \multicolumn{7}{|c|}{ Component } \\
\hline & 1 & 2 & 3 & 4 & 5 & 6 \\
\hline Presentation skills & .759 & & & & & \\
\hline Project management & .724 & & & & & \\
\hline Creative thinking & .713 & & & & & \\
\hline Information technology competence & .708 & & & & & \\
\hline Focused on outcomes & .707 & & & & & \\
\hline
\end{tabular}




\begin{tabular}{|c|c|c|c|c|c|c|}
\hline Inter or multi-disciplinary perspective & .701 & & & & & \\
\hline Financial risk analysis & 653 & & & & & \\
\hline Economics & .634 & & & & & \\
\hline Statistics & .629 & & & & & \\
\hline Teamwork & & .845 & & & & \\
\hline English language & & .829 & & & & \\
\hline Listen effectively & & .806 & & & & \\
\hline Communication in written format & & .790 & & & & \\
\hline Oral communication & & .765 & & & & \\
\hline Negotiation skills & & .661 & & & & \\
\hline Ability to analyse and reason logically & & & .736 & & & \\
\hline Legal regulatory perspective & & & .727 & & & \\
\hline Problem solving & & & .717 & & & \\
\hline Critical thinking & & & .712 & & & \\
\hline Decision making & & & .681 & & & \\
\hline Cost and management accounting & & & .671 & & & \\
\hline International global perspective & & & .644 & & & \\
\hline Financial accounting & & & .632 & & & \\
\hline Leadership & & & & .790 & & \\
\hline Marketing/clients focus & & & & .769 & & \\
\hline Understanding group dynamics & & & & .761 & & \\
\hline Strategic management & & & & .737 & & \\
\hline Self-initiative & & & & & .782 & \\
\hline Flexibility and adaptability & & & & & .751 & \\
\hline Personal attributes & & & & & .737 & \\
\hline Engage in lifelong learning & & & & & .735 & \\
\hline Think and behaves ethically & & & & & & .793 \\
\hline Work effectively in diversified cultural settings & & & & & & .761 \\
\hline Tolerate ambiguity & & & & & & .714 \\
\hline Independent thinking & & & & & & .560 \\
\hline Cronbach alpha $(\alpha)$ & .883 & .802 & .848 & .855 & .832 & .815 \\
\hline
\end{tabular}

Extraction Method: Principal Component Analysis.

Rotation Method: Varimax with Kaiser Normalization.

a. Rotation converged in 6 iterations.

b. Only cases for which group = Only Employers are used in this analysis phase. 
Table 8, the rotated pattern matrix shows the loaded items in 6 components, ranging from 0.560 to 0.845 component loading, which satisfy the minimum component loading criteria presented by Churchill (1979).

Once the components have been extracted, one can determine the extent to which the items (skills) in a component are loaded. In this study, for all of the extracted 6 components, Cronbach's alphas were more than 0.7 and, therefore, they were all in the acceptable range from an internal consistency point of view (see Table 8). Thus, as a result of Principal Component Analysis, Table 9 in this analysis shows the 6 extracted components are those that are required in terms of skill-based education for accounting employment purposes.

Table 9: Representing the Six Extracted Components of Skills Based on the Results of Principal Component Analysis

\begin{tabular}{|c|c|c|c|c|c|}
\hline $\begin{array}{l}\text { Component } \\
\text { 1/ Apprecia- } \\
\text { tive skills }\end{array}$ & $\begin{array}{l}\text { Component } \\
\text { 2/ Interper- } \\
\text { sonal skills }\end{array}$ & $\begin{array}{l}\text { Component } \\
3 / \text { Technical } \\
\text { and Function- } \\
\text { al skills }\end{array}$ & $\begin{array}{l}\text { Component } \\
\text { 4/Organisa- } \\
\text { tional and } \\
\text { Business } \\
\text { management } \\
\text { skills }\end{array}$ & $\begin{array}{l}\text { Component } \\
\text { 5/Personal } \\
\text { skills }\end{array}$ & $\begin{array}{l}\text { Component } \\
\text { 6/Profession- } \\
\text { al skills }\end{array}$ \\
\hline $\begin{array}{l}\text { Presentation } \\
\text { skills }\end{array}$ & Teamwork & $\begin{array}{c}\text { Ability to anal- } \\
\text { yse and reason } \\
\text { logically }\end{array}$ & Leadership & Self-initiative & $\begin{array}{l}\text { Think and be } \\
\text { haves ethically }\end{array}$ \\
\hline $\begin{array}{l}\text { Project man- } \\
\text { agement }\end{array}$ & $\begin{array}{l}\text { English lan- } \\
\text { guage }\end{array}$ & $\begin{array}{l}\text { Legal regulato- } \\
\text { ry perspective }\end{array}$ & $\begin{array}{l}\text { Marketing/ } \\
\text { clients focus }\end{array}$ & $\begin{array}{c}\text { Flexibility and } \\
\text { adaptability }\end{array}$ & $\begin{array}{l}\text { Work effec- } \\
\text { tively in diver- } \\
\text { sified cultural } \\
\text { settings }\end{array}$ \\
\hline $\begin{array}{l}\text { Creative } \\
\text { thinking }\end{array}$ & $\begin{array}{l}\text { Listen effec- } \\
\text { tively }\end{array}$ & $\begin{array}{l}\text { Problem } \\
\text { solving }\end{array}$ & $\begin{array}{l}\text { Understand- } \\
\text { ing group } \\
\text { dynamics }\end{array}$ & $\begin{array}{l}\text { Personal } \\
\text { attributes }\end{array}$ & $\begin{array}{l}\text { Tolerate ambi } \\
\text { guity }\end{array}$ \\
\hline $\begin{array}{l}\text { Information } \\
\text { technology } \\
\text { competence }\end{array}$ & $\begin{array}{l}\text { Communica- } \\
\text { tion in written } \\
\text { format }\end{array}$ & $\begin{array}{l}\text { Critical } \\
\text { thinking }\end{array}$ & $\begin{array}{c}\text { Strategic man- } \\
\text { agement }\end{array}$ & $\begin{array}{l}\text { Engage in life- } \\
\text { long learning }\end{array}$ & $\begin{array}{l}\text { Independent } \\
\text { thinking }\end{array}$ \\
\hline $\begin{array}{c}\text { Focused on } \\
\text { outcomes }\end{array}$ & $\begin{array}{l}\text { Oral commu- } \\
\text { nication }\end{array}$ & $\begin{array}{c}\text { Decision } \\
\text { making }\end{array}$ & & & \\
\hline $\begin{array}{l}\text { Inter or } \\
\text { multi-dis- } \\
\text { ciplinary } \\
\text { perspective }\end{array}$ & $\begin{array}{l}\text { Negotiation } \\
\text { skills }\end{array}$ & $\begin{array}{c}\text { Cost and } \\
\text { management } \\
\text { accounting }\end{array}$ & & & \\
\hline
\end{tabular}




\begin{tabular}{|c|l|c|l|l|l|}
\hline $\begin{array}{c}\text { Financial risk } \\
\text { analysis }\end{array}$ & $\begin{array}{c}\text { International } \\
\text { global perspec- } \\
\text { tive }\end{array}$ & & & \\
\hline Economics & & $\begin{array}{c}\text { Financial } \\
\text { accounting }\end{array}$ & & & \\
\hline Statistics & & & & & \\
\hline
\end{tabular}

Six sets of skills are presented in Table 9, which educators can use in order to improve skills acquisition for accounting employment purposes. As such, $\mathrm{RO} 2$ is validated.

\section{Conclusion}

This research brings a new theoretical perspective on skills acquisition from the perspective of the professional accounting institutes. Professional accounting institutes are quite different to the universities where most of the research regarding skills development has been conducted previously (see Kavanagh \& Drennan, 2007; 2008, Kavanagh et al., 2009, Jackling \& Keneley, 2009). These differences relate to funding structure, employment policy, reward system, curriculum development, examination systems, and students' intake criteria. These differences suggest a different level of 'skills acquisition shortfall' from the context of professional accounting institution's perspective when compared with universities. Further, this argument is augmented by Greatbatch and Lewis (2007) who argued that, "generic employability skills and attributes are context sensitive, which is to say they may vary in detail between different work contexts" (p. 7), and Jackling and Keneley (2009) who stated that, "A key argument for embedding skill development into the teaching program is that the development of such skills is more relevant when placed within the context of the discipline under study" (p. 10).

Hence, this research offers a unique theoretical understanding regarding 'skills acquisition shortfall' from professional accounting institutions perspective and not from universities promoting accounting education in their academic programs. In response to RO1, out of the 35 investigated skills in this research, 24 skills were where accounting educators failed to develop skills in students, as expected by employers. Arguably, this pedagogical shortfall reflects 'skills acquisition shortfall' which can be remedied by giving special attention to skills where a statistically significant level of the gap has been noticed among educators' performance and employers' expectations (Category 2 in Table 6).

The findings of $\mathrm{RO} 2$ in this research has also an important implication for accounting curriculum perspective. Most of the individuals generally have a belief that 
accounting education is mathematical in nature. Thus, resulting, declining accounting institutes enrolment rates. This aspect is well documented in the accounting literature (see Kullberg et al., 1989; Felton, Buhr, \& Northey, 1994; Hermanson et al., 1996; Marriott \& Marriott, 2003; Wells, 2006; ICAA, 2002; Jackling \& Calero, 2006). This false belief is implied because of the lack of knowledge regarding accounting education. This false belief can be remedied through the findings of RO2 (see Table 9), that is, extracted 6 components of skills. Now, these 6 components of skills could be viewed as a skills acquisition framework from the context of accounting job-market. Additionally, those universities which are planning to start accounting degrees can also take initial guidance from this skill acquisition framework in the design of their academic programs.

\subsection{Recommendations for Future Research:}

In consideration to future research, education institutions should have regard to the views and expectations of students as they are an essential part of the education system (Jackling \& Keneley, 2009). De Lange et al. (2006) has also acknowledged the students as a key stakeholder in the learning process. Hence in alignment with the continuity of this research, in future, consideration should be given to reporting the students' views, especially over the constituents of performance gap.

\section{References}

Accounting Education Change Commission. (1990). Position statement number one: Objectives of education for accountants. Issues in Accounting Education, 5(2), 307-312.

Albrecht, W. S., \& Sack, R. J. (2000). Accounting education: Charting the course through a perilous future. Sarasota, FL: American Accounting Association.

American Institute of Certified Public Accountants. (1998). AICPA core competency framework for entry into the accounting profession: Report presented to American Institute of Certified Public Accountants.

Askary, S. (2006). Accounting professionalism-a cultural perspective of developing countries. Managerial Auditing Journal, 21(1), 102-111.

Australian Chamber of Commerce and Industry. (2002). Employability skills-an employer perspective. Getting what employers want out of the too hard basket: Report presented to Australian Chamber of Commerce and Industry. Retrieved from http://www.voced.edu.au/content/ngv\%3A9178

Awayiga, J. Y., Onumah, J. M., \& Tsamenyi, M. (2010). Knowledge and skills development of accounting graduates: The perceptions of graduates and employers in Ghana. Accounting Education: An International Journal, 19(1-2), 139-158.

Blundell, R., Dearden, L., Meghir, C., \& Sianesi, B. (1999). Human capital investment: the returns 
from education and training to the individual, the firm and the economy. Fiscal studies, 20(1), 1-23.

Brown, B. L. (2002). Generic skills in career and technical education (Myths and realities). Columbus, OH: ERIC Publications

Bui, B., \& Porter, B. (2010). The expectation-performance gap in accounting education: An exploratory study. Accounting Education: An International Journal, 19(1-2), 23-50.

Campbell, A. (2010). Developing generic skills and attributes of international students: The (ir)relevance of the Australian university experience. Journal of Higher Education Policy and Management, 32(5), 487-497.

Certified Practising Accountants. (2008). International accreditation guidelines for accounting degree programs: Report presented to Certified Practising Accountants.

Churchill Jr., G. A. (1979). A paradigm for developing better measures of marketing constructs. Journal of marketing research, 16(1), 64-73.

Confederation of British Industry. (2009). Future fit: preparing graduates for the world of work: Report presented to Confederation of British Industry. Retrieved from http://www.ed.ac.uk/files/atoms/files/ cbiuuk-futurefit-mar2009.pdf

Coopers \& Lybrand. (1998). Skills development in higher education: Report presented to Department for Education and Employment.

Council for Industry and Higher Education. (1996). Helping students towards success at work - Declaration of intent: Report presented to Council for Industry and Higher Education

Cranmer, S. (2006). Enhancing graduate employability: best intentions and mixed outcomes. Studies in Higher Education, 31(2), 169-184.

De Lange, P., Jackling, B., \& Gut, A. M. (2006). Accounting graduates' perceptions of skills emphasis in undergraduate courses: an investigation from two Victorian universities. Accounting $\mathcal{E}$ Finance, 46(3), 365-386.

Dearing, Ron. (1997). Higher education in the learning society [Dearing report]: Report presented to National Committee of Inquiry into Higher Education. Retrieved from http://www.voced.edu.au/content/ ngv\%3A27137

Department of Trade and Industry. (2005). A literature review on skills and innovation: How does successful innovation impact on the demand for skills and how do skills drive innovation? Report presented to Department of Trade and Industry. Retrieved from https://www.escholar.manchester.ac.uk/uk-ac-man-scw:5b735

Fechner, H. H., \& Kilgore, A. (1994). The influence of cultural factors on accounting practice. The International Journal of Accounting, 29(3), 265-277.

Felton, S., Buhr, N., \& Northey, M. (1994). Factors influencing the business student's choice of a career in chartered accountancy. Issues in Accounting education, 9(1), 131. 
Fitzsimons, P. (1999). Human capital theory and education. The encyclopedia of education. London: Macmillan

Gati, I. (1998). Using career-related aspects to elicit preferences and characterize occupations for a better person-environment fit. Journal of Vocational Behavior, 52(3), 343-356.

Gray, S. J. (1988). Towards a theory of cultural influence on the development of accounting systems internationally. Abacus, 24(1), 1-15.

Gray, R., \& Collison, D. (2002). Can't see the wood for the trees, can't see the trees for the numbers? Accounting education, sustainability and the public interest. Critical Perspectives on Accounting, 13(56), $797-836$.

Greatbatch, D., \& Lewis, P. (2007). Generic employability skills II. Report presented to Centre for Developing and Evaluating Lifelong Learning. Retrieved from http://www.voced.edu.au/content/ngv\%3A16634

Hair, J., Black, B., Babin, B.J., Anderson, R., \& Tatham, R. (2006) Multivariate data analysis (6 ${ }^{\text {th }}$ ed). New Jersey: Pearson Prentice Hall.

Harvey, L., \& Bowers-Brown, T. (2004). Employability cross country comparisons: Article contributed to Centre for Research and Evaluation at Sheffield Hallam University. Retrieved from: http://ww2.prospects.ac.uk/ cms/ShowPage/Home_page/Members___Log_in/Labour_market_information/Graduate_Market_Trends/Employability_cross_country_comparisons__Winter_04_05_p!epmjlid

Hassall, T., \& Joyce, J. (2001). Approaches to learning of management accounting students. Education + Training, 43(3), 145-153.

Hassall, T., Joyce, J., Montaño, J. L. A., \& Anes, J. A. D. (2005). Priorities for the development of vocational skills in management accountants: A European perspective. Accounting Forum, 29(4), 379-394.

Hassall, T., Joyce, J., Montaño, J. L. A., \& Anes, J. A. D. (2003). The vocational skills gap for management accountants: the stakeholders' perspectives. Innovations in Education and Teaching International, 40(1), 78-88.

Hassall, T., Joyce, J., Montano, J. L. A., \& Anes, J. A. D. (1999). The employers' priorities: vocational skills and capabilities for management accountants. Industry and Higher Education, 15(6), 421-429.

Hermanson, R. H., Deines, D. S., Eldridge, C., Hermanson, D. R., Ivancevich, S. H., \& Williams, D. Z. (1996). Strategies for recruiting the best and brightest students into accounting: American Accounting Association teaching and curriculum section. Journal of Accounting Education, 14(3), 347-365.

Hillage, J., \& Pollard, E. (1998). Employability: Developing a framework for policy analysis. London: Department for Education and Employment.

Her Majesty's Treasury. (1997). UK employment action plan: Report presented to Her Majesty's Treasury.

Institute of Chartered Accountants in Australia. (2002). Trends in accounting at Australian universities: Report presented to Institute of Chartered Accountants in Australia. 
Institute of Chartered Accountants in England and Wales. (2010). ACA advanced staged syllabus: Report presented to Institute of Chartered Accountants in England and Wales.

International Federation of Accountants. (2008) Framework for international education pronouncements: Report presented to International Federation of Accountants. Retrieved from http://www.fiscontexpert. ro/libs/docs/standarde_internationale_de_educatie.pdf

Jackling, B., \& Calero, C. (2006). Influences on undergraduate students' intentions to become qualified accountants: Evidence from Australia. Accounting Education: An International Journal, 15(4), 419-438.

Jackling, B., \& Keneley, M. (2009). Perceptions of generic skill development: International and local accounting students in Australia. Paper presented at the Accounting and Finance Association of Australia and New Zealand Annual Conference, Adelaide, Australia. Retrieved from http://dro.deakin.edu.au/ view/DU:30022682

Jackling, B., \& Watty, K. (2010). Generic skills. Accounting Education, 19(1-2), 1-3.

Jones, A. A., \& Sin, S. (2003) Generic skills in accounting: Competencies for students and graduates. Frenchs Forest, N.S.W: Pearson/Prentice Hall.

Jones, A. (2010). Generic attributes in accounting: the significance of the disciplinary context. Accounting Education: An International Journal, 19(1-2), 5-21.

Kavanagh, M., \& Drennan, L. (2007). Graduate attributes and skills: Are we as accounting academics delivering the goods? Paper presented at the Accounting and Finance Association of Australia and New Zealand Annual Conference, Gold Coast, Australia. Retrieved from https://eprints.usq.edu.au/6367/

Kavanagh, M., Hancock, P., Howieson, B., Kent, J., \& Tempone, I. (2009). Stakeholders' perspectives of the skills and attributes for accounting graduates. Paper presented at the Accounting and Finance Association of Australia and New Zealand Annual Conference, Adelaide, Australia. Retrieved from https://eprints.usq.edu.au/6929/

Kavanagh, M. H., \& Drennan, L. (2008). What skills and attributes does an accounting graduate need? Evidence from student perceptions and employer expectations. Accounting $\mathcal{G}$ Finance, 48(2), 279-300.

Knight, P. T., \& Yorke, M. (2003). Employability and good learning in higher education. Teaching in Higher education, 8(1), 3-16.

Kullberg, D. R., Gladstone, W. L., Scanlon, P. R., Cook, J. M., Groves, R. J., Horner, L. D., ... \& Kangas, E. A. (1989). Perspectives on education: Capabilities for success in the accounting profession. New York, NY: Arthur Anderson \& Co.

Lin, Z. J., Xiong, X., \& Liu, M. (2005). Knowledge base and skill development in accounting education: Evidence from China. Journal of Accounting Education, 23(3), 149-169.

Marriott, P. R. U., \& Marriott, N. (2003). Are we turning them on? A longitudinal study of undergraduate accounting students' attitudes towards accounting as a profession. Accounting education, 12(2), 
113-133.

McQuaid, R. W., \& Lindsay, C. (2005). The concept of employability. Urban studies, 42(2), 197-219.

Milner, M. M., \& Hill, W.Y. (2008). Examining the skills debate in Scotland. International Journal of Management Education, 6(3), 1-13.

Morley, L. (2001). Producing new workers: Quality, equality and employability in higher education. Quality in higher education, 7(2), 131-138.

Montano, J. L. A., Donoso, J. A., Hassall, T., \& Joyce, J. (2001). Vocational skills in the accounting professional profile: The Chartered Institute of Management Accountants (CIMA) employers' opinion. Accounting Education, 10(3), 299-313.

Norusis, M. (1992). SPSS for Windows professional statistics release 6.0. Chicago, IL. Prentice Hall.

Precision Consultancy. (2007). Graduate employability skills: Report presented to Business, Industry and Higher Education Collaboration Council. Retrieved from http://aces.shu.ac.uk/employability/resources/ GraduateEmployabilitySkillsFINALREPORT1.pdf

Perera, M. H. B., \& Mathews, M. R. (1990). The cultural relativity of accounting and international patterns of social accounting. Advances in international accounting, 3(3), 215-251.

Quality Assurance Agency. (2009). Learning from ELIR 2003-07: Emerging approaches to employability and personal development planning: Report presented to Quality Assurance Agency of Higher Education. Retrieved from http://dera.ioe.ac.uk/451/

Quality Assurance Agency (2007). Subject Benchmark statement: accounting: Report presented to Quality Assurance Agency of Higher Education. Retrieved from http://www.qaa.ac.uk/en/Publications/ Documents/SBS-Accounting-16.pdf

Pinar, W.F. (2004). What is curriculum theory? Mahwah, NJ: Lawrence Erlbaum Associates, Publishers

Tabachnick, B. G., \& Fidell, L.S. (2007). Using multivariate statistics. New Jersey, NJ: Pearson International.

Tan, L. M., Fowler, M. B., \& Hawkes, L. (2004). Management accounting curricula: Striking a balance between the views of educators and practitioners. Accounting Education, 13(1), 51-67.

Schiro, M.S. (2012). Curriculum theory: Conflicting visions and enduring concerns. Boston, USA: Sage Publications.

Wellman, M. N. (2010). The employability attributes required of new marketing graduates. Marketing Intelligence $\mathcal{E}$ Planning, 28(7), 908-930.

Wells, P. K. (2006). The supply of accounting graduates in New Zealand, Auckland, NZ: Sprint Print.

Willcoxson, L., Wynder, M., \& Laing, G. K. (2010). A whole-of-program approach to the development of generic and professional skills in a university accounting program. Accounting Education, 19(1), 65-91. 
Yorke, M. (2006). Employability in higher education: What it is, what it is not, York, UK: The Higher Education Academy. 


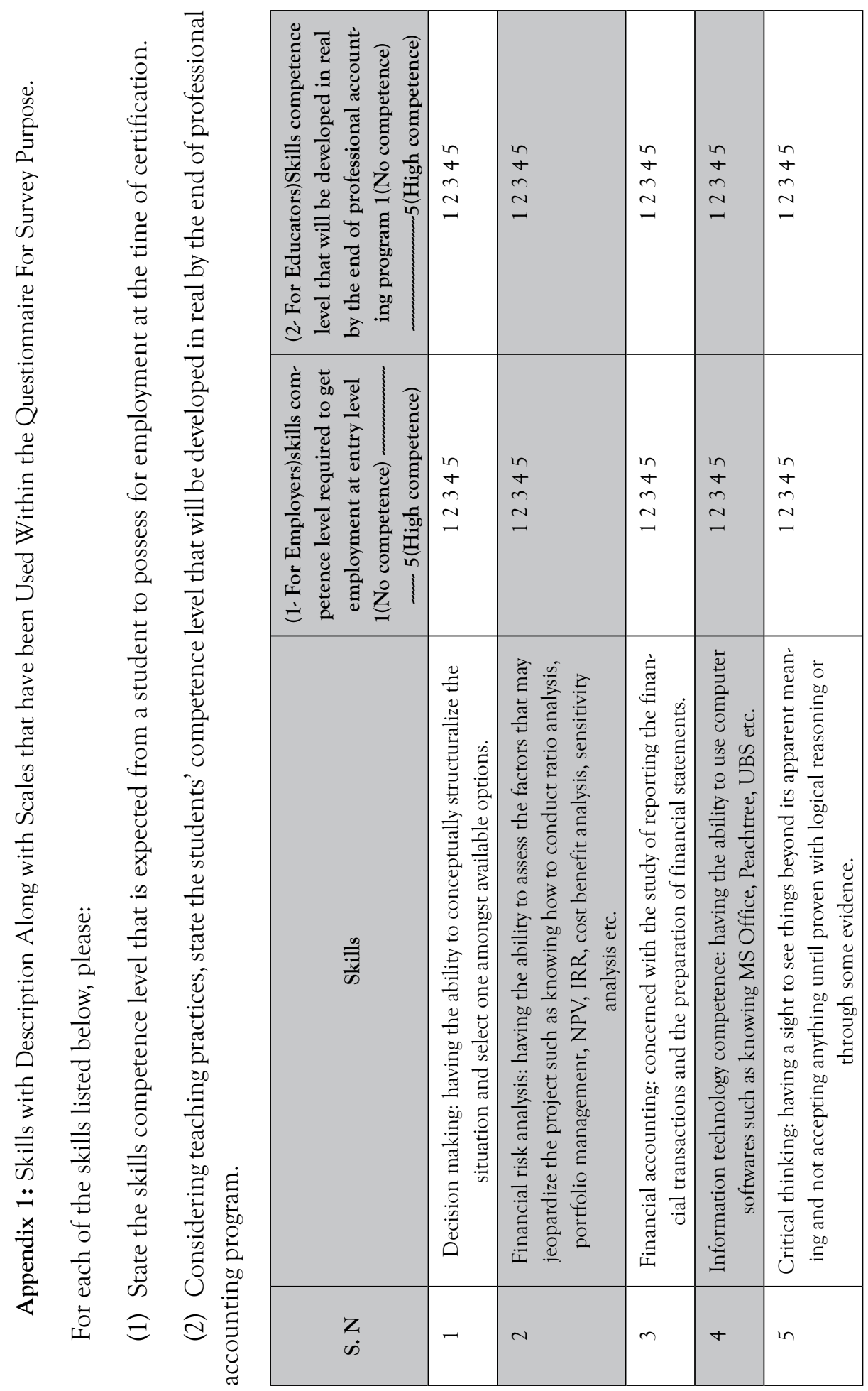




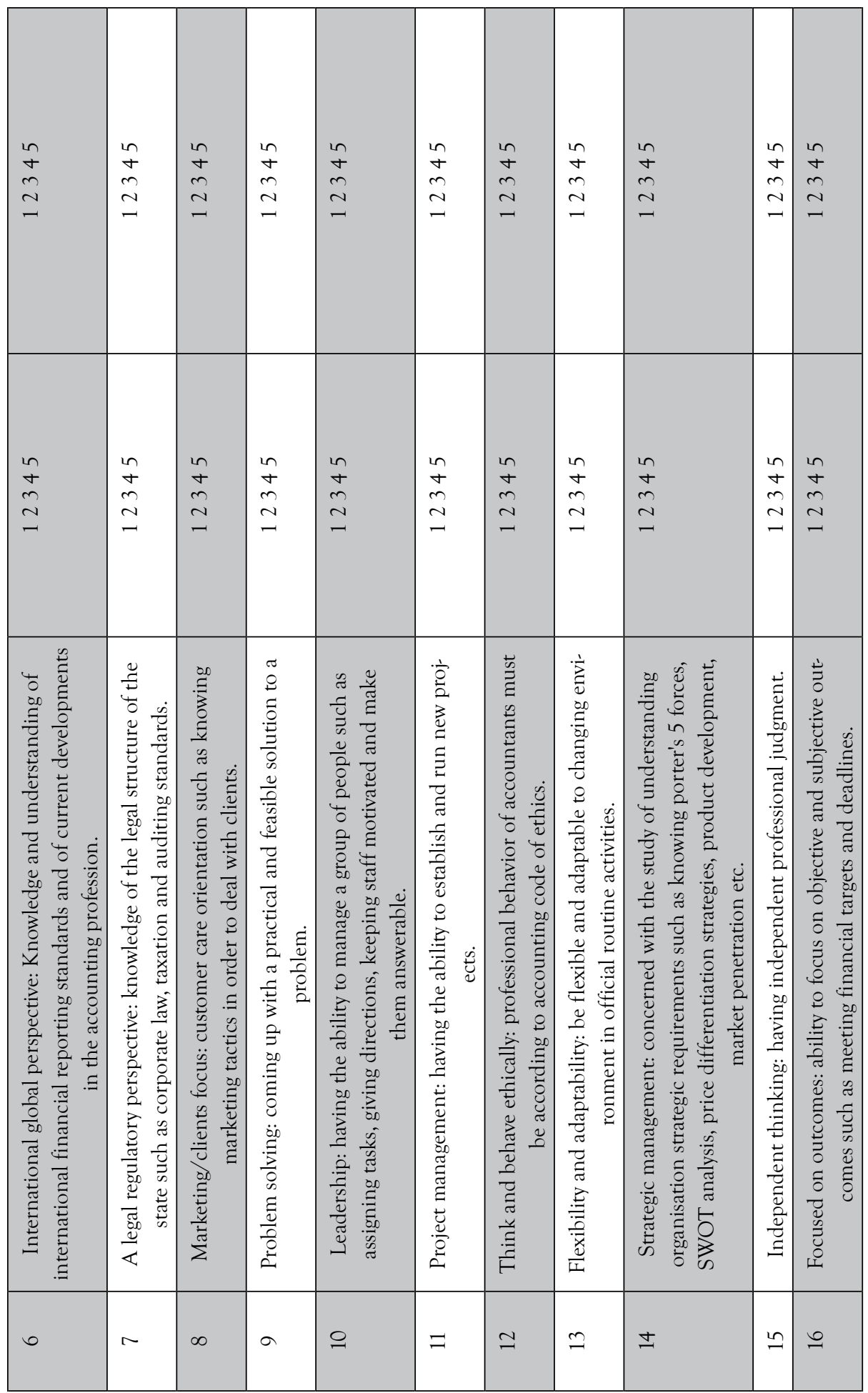




\begin{tabular}{|c|c|c|c|c|c|c|c|c|c|c|c|}
\hline $\begin{array}{l}n \\
\stackrel{n}{*} \\
\sim \\
\sim\end{array}$ & $\begin{array}{l}n \\
+ \\
\sim \\
\sim\end{array}$ & $\begin{array}{l}n \\
\stackrel{1}{*} \\
\sim \\
\sim\end{array}$ & \begin{tabular}{l}
$n$ \\
\multirow{1}{*}{} \\
$\stackrel{2}{\sim}$ \\
$\sim$
\end{tabular} & $\begin{array}{l}n \\
\dot{\sim} \\
\tilde{\sim} \\
\sim\end{array}$ & \begin{tabular}{l}
$n$ \\
\multirow{2}{*}{} \\
$\sim$ \\
$\sim$
\end{tabular} & $\begin{array}{l}n \\
\stackrel{n}{+} \\
\stackrel{2}{\sim} \\
\sim\end{array}$ & \begin{tabular}{l}
$n$ \\
\multirow{r}{*}{} \\
$\stackrel{-}{\sim}$
\end{tabular} & $\begin{array}{l}n \\
\stackrel{n}{+} \\
\stackrel{2}{\sim} \\
\sim\end{array}$ & $\begin{array}{l}n \\
\stackrel{n}{*} \\
\stackrel{2}{\sim} \\
\sim\end{array}$ & $\begin{array}{l}n \\
\stackrel{n}{*} \\
\stackrel{2}{\sim}\end{array}$ & $\begin{array}{l}n \\
\stackrel{1}{+} \\
\stackrel{2}{\sim} \\
\sim\end{array}$ \\
\hline $\begin{array}{l}n \\
\stackrel{n}{*} \\
\sim \\
\sim\end{array}$ & $\begin{array}{l}n \\
+ \\
\stackrel{2}{\sim} \\
\sim\end{array}$ & \begin{tabular}{l}
$n$ \\
\multirow{2}{*}{} \\
$\stackrel{2}{\sim}$ \\
$=$
\end{tabular} & \begin{tabular}{l}
$n$ \\
\multirow{+}{*}{} \\
$\stackrel{2}{\sim}$ \\
$\sim$
\end{tabular} & $\begin{array}{l}n \\
\stackrel{1}{+} \\
\sim \\
\sim \\
\sim\end{array}$ & 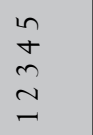 & $\begin{array}{l}n \\
\dot{v} \\
\sim \\
\sim\end{array}$ & $\begin{array}{l}n \\
\dot{n} \\
\stackrel{n}{\sim} \\
\sim\end{array}$ & $\begin{array}{l}n \\
\dot{+} \\
\stackrel{2}{\sim} \\
\sim\end{array}$ & $\begin{array}{l}n \\
\stackrel{n}{*} \\
\sim \\
\sim\end{array}$ & $\begin{array}{l}n \\
\stackrel{+}{*} \\
\sim \\
\sim\end{array}$ & \begin{tabular}{l}
$n$ \\
\multirow{2}{*}{} \\
$\sim$ \\
$\sim$
\end{tabular} \\
\hline 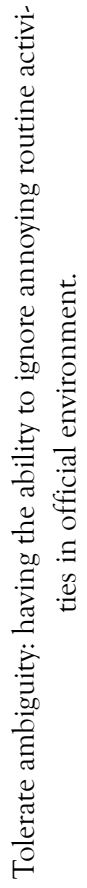 & 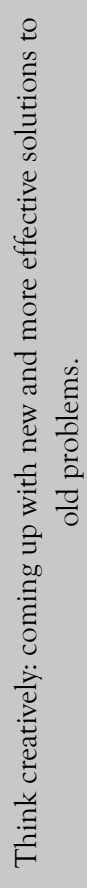 & 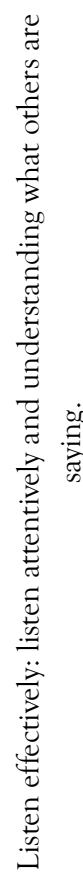 & 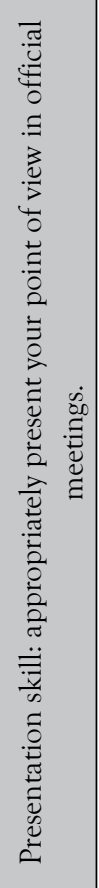 & 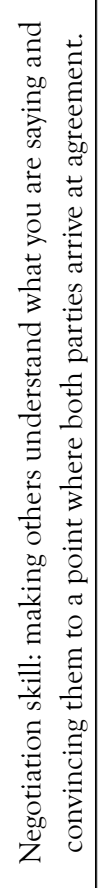 & 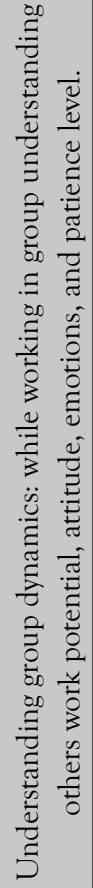 & 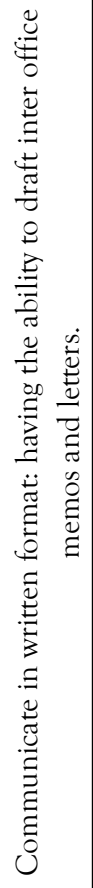 & 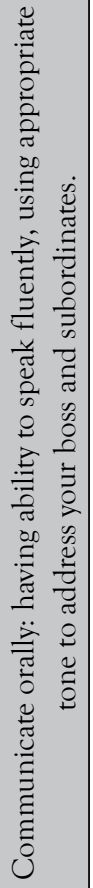 & 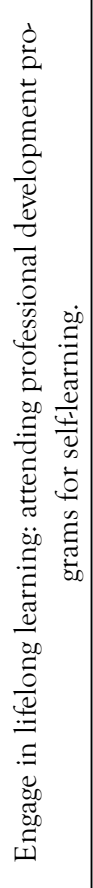 & 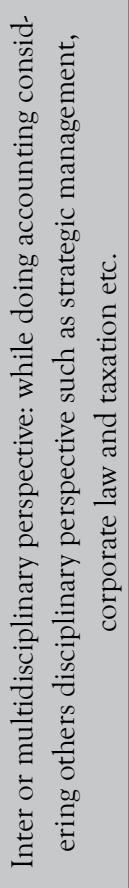 & 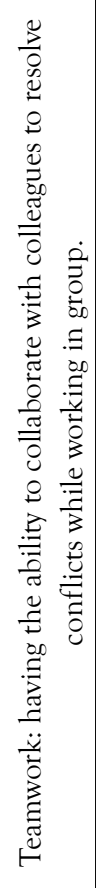 & 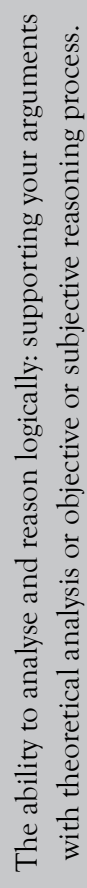 \\
\hline$\simeq$ & $\stackrel{\infty}{=}$ & $\stackrel{2}{2}$ & సి & $\vec{\sim}$ & $\widetilde{\sim}$ & $\ddot{\sim}$ & $\stackrel{ \pm}{\sim}$ & $\stackrel{2}{\sim}$ & $\stackrel{\circ}{\sim}$ & $\approx$ & $\stackrel{\infty}{\sim}$ \\
\hline
\end{tabular}




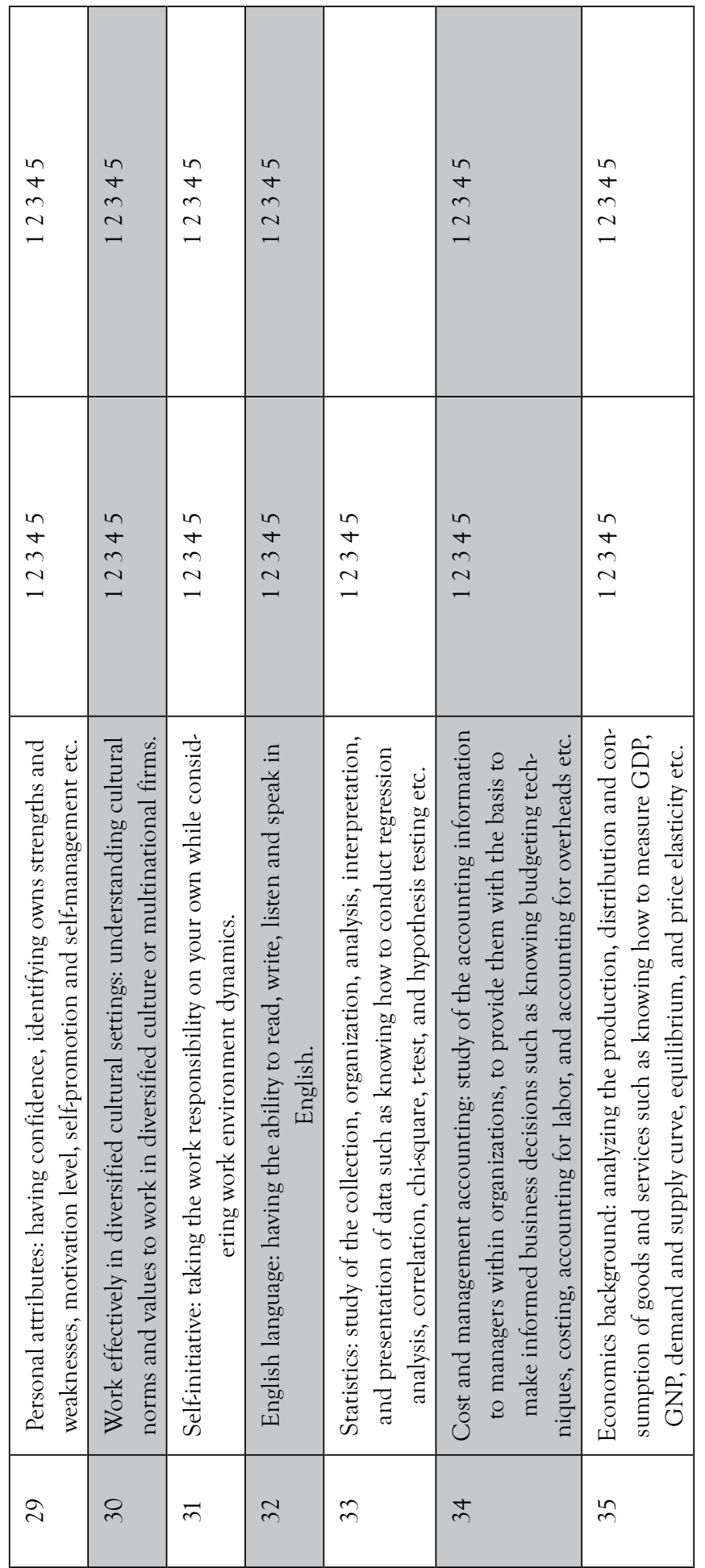


